\title{
An Analysis on Development Predicaments of Privately-owned Small \& Medium Enterprises and Countermeasures
}

\author{
Hanbing Tan and Wenchao Zhang \\ Shijiazhuang Vocational Technology Institute, 050081 Shijiazhuang Hebei, China
}

\begin{abstract}
Through field survey on 100 privately-owned small and medium enterprises in Shijiazhuang of Hebei province and relevant data collection, the author finds that their development has been severely impeded by such phenomena as financing dilemma, retention difficulty and chaotic management. On the basis of theories of management and social development, reasons for development predicaments are systematically analyzed by means of combining qualitative and quantitative studies. In the meantime, based on relevant economic theories and reference to advanced experience and theories at home and abroad, the author proposes countermeasures and suggestions for development predicament of SMEs, which are relatively suitable for Shijiazhuang City.
\end{abstract}

Keywords. privately-owned small and medium enterprises; development predicament; countermeasures

\section{Introduction}

With the improvement of economic marketization and changes of trade environment, privately-owned small and medium enterprises develop rapidly, playing an increasingly important role in economy. The statistics show that taxes paid by privately operated economy account for $48 \%$ of the whole city's fiscal revenue in 2012, holding up a half of the fiscal revenue in Shijiazhuang. The total output of industrial privately-owned SMEs reaches 85.928 billion yuan, with a year-on-year growth of $6.9 \%$, value added of 26.328 billion yuan and comparable price growth of $7.32 \%{ }^{[1]}$. Affected by macroeconomic situation, many privately-owned SMEs have encountered a series of unfavorable factors since 2008, such as financing difficulty, shrinking market demand at home and abroad, rising prices of raw materials, and rising labor cost, etc. Meanwhile, they are faced with great challenges, especially when their own problems are highlighted in the economic environment. Therefore, the author makes an attempt in analyzing development bottlenecks of privately-owned SMEs in Shijiazhuang and the relevant reasons, as well as in seeking solutions through learning advanced experience from home and abroad, so as to boost the healthy development of privately-owned SMEs in Shijiazhuang and even the whole city's economy.

\section{Current situation and analysis of pri- vately-owned SMEs in Shijiazhuang}

The author conducted a questionnaire survey on 100 privately-owned SMEs in Shijiazhuang, mainly concern- ing development predicaments and suggestions. Meanwhile, a survey combining interview and questionnaire on certain individual enterprises was also carried out so as to make up for what was uninvolved in the questionnaire. 92 valid questionnaires were collected back. The survey was carried out in following aspects:

\subsection{Instability and poor development}

It found from the interview that most privately-owned SMEs manage extensively with poor technology and management. They participate in market competition by relying mainly on "low cost, low price and low profit" while remain backward in aspects such as business management, cultural construction, brand operation and technological innovation. Staff problems like "low wages, incomplete social insurance, large labor intensity, and poor working environment" are ubiquitous.

\subsection{Capital}

Data from the survey showed that the main capital source of privately-owned SMEs in Shijiazhuang includes such financing channels as own capital, private lending, internal financing, bank loan and etc. It found from the survey that enterprises with their own capitals take a larger proportion that is 70 out of $92 ; 34$ enterprises with bank loan take the proportion of $36.96 \% ; 30$ enterprises with internal financing account for $32.61 \%$; 22 enter-prises take loans from credit cooperatives and rural foundations, taking 23.91\%; and there are also 6 enter-prises finance from other ways, which account for $6.52 \%$. Most enter- 
prises in the interview believe that state-owned banks are reluctant to take out loans due to their high threshold. Although loans can be taken from privately-owned banks more easily, it is still difficult to afford high loan cost involving mortgage for small enterprises, who recommend lowering the threshold, reducing interest rate and developing credit agencies. Survey data indicated that privately-owned SMEs have financing difficulties with narrow channel.

Loans for enterprises are mainly used for expanding production, accounting for $71 \%$ of the total. $49 \%$ of the enterprises use their loans for technological updating, $23 \%$ for maintaining normal production, and $6 \%$ for other aspects. When these enterprises are short in own capital, a great loss would be brought to them due to a large number of orders without timely financing.

From the investigation on relation between involved industries and financing ways of privately-owned SMEs, it can be found that there is a great difference in choosing financing ways due to various business operations. Aside from the above-mentioned five financing ways, enterprises from different industries choose various financing combinations. There are relatively more financing ways for pharmaceutical enterprises while less for clothing industry, real estate, catering and etc.

It can be also found from the survey that huge financing gap has severely hindered the development of some privately-owned SMEs, in spite of strongly support from national policies and local government. Besides, there is a portion of enterprises being forced to face high financing costs, because they can only rely on private financing instead of enjoying preferential policies ${ }^{[2]}$. Even if they are allowed to take loans from bank, the success is still strongly restricted by such factors as guarantee, procedure and high interest rate.

A conclusion can be drawn through the above survey and analysis: financing difficulty exists as a ubiquitous phenomenon for privately-owned SMEs, increasingly becoming an obstacle to development. Banks now serve as the main financing channel, but relatively high financing cost further restricts financing amount.

\subsection{Technology}

At present, the technological equipment level of privately-owned SMEs in Shijiazhuang is generally low with small output and mainly labor-intensive products. Compared with large enterprises, they lag behind not only in production equipment but also in production and R\&D capabilities due to the scale of production and capital. This is the bottleneck of development for privatelyowned SMEs, namely poor capability of independent innovation. Firstly, funds for research and development are insufficient. These enterprises can hardly maintain funding for daily operations, let alone funds for innovative R\&D. Secondly, it is difficult to implement policies. Aiming at promoting innovation ability of enterprises, both the nation and local government have successively formulated and issued some preferential policies, of which most privately-owned SMEs are ignorant, so it is difficult to put these policies into full implementation.
Thirdly, profitability and long-term development ability of enterprises are seriously limited by poor consciousness of property rights, small proportion of products with independent intellectual property rights and self-owned brands, as well as weak competitiveness.

\subsection{Professionals}

Statistics showed that privately-owned SMEs are severely lacking in excellent professionals and management personnel. The brain-drain situation remains an urgent problem for privately-owned SMEs in Shijiazhuang that it is difficult to recruit and retain personnels. Enterprises would generally offer low pay and incomplete social insurance to save costs, resulting in generally low quality of staff. A large majority of enterprises are unable to conduct strict and standard management of high quality, limiting their long-term and healthy development. Some enterprise owners are even shortsighted, paying attention only to short-term profit and closing down as soon as money is earned. This is an important reason why privately-owned SMEs find it difficult to recruit professionals and management personnels of high quality.

\section{Countermeasures and suggestions for further promotion of development of privately-owned SMEs in Shijiazhuang}

\subsection{Alleviate financing difficulty intently}

\subsubsection{Government should assist to establish effective financing service platform}

A) Expand financing channels for privately-owned SMEs. Take piloting small loan companies for in-stance, some privately-owned SMEs can be selected to try and then sum up experience in practice for future. Qualified natural person, legal person and other social organizations with strength should be supported to sponsor small loan companies so as to expand financing channels and enlarge financing coverage.

B) Gradually standardize evaluation and registration of mortgage loan of privately-owned SMEs, including simplifying procedure, reducing and standardizing relevant expenses, formulating and improving matched laws and regulations, cracking down on misconduct like debt avoidance, building up debt recovery system and investigating for legal responsibility of serious violators, so as to create a better environment and provide legal protection for bank financing.

C) Establish credit guarantee companies for privatelyowned SMEs. According to successful experiences of Wenzhou City and other places in terms of establishing credit guarantee companies, certain measures shall be taken to establish governmental credit guarantee companies in Shijiazhuang City, the main service targets of which are privately-owned SMEs and the coverage of which can be adjusted properly in accordance with owner's major business. Assets and risk evaluation system and decision-making process that are suitable for enter- 
prises shall be established, and relevant risk prevention measures shall be formulated as well ${ }^{[3]}$.

\subsubsection{Financial institutions shall effectively reduce bank financing cost and enhance their conscious- ness of providing loan service for privately-owned SMES.}

A) Appropriately cut the benchmark interest rate. At present, the cost of financing loan from financial institutions is relatively high for privately-owned SMEs in Shijiazhuang City, which is even $200 \%$ of the benchmark interest rate. Normal development of enterprises is hindered by increased cost. The benchmark interest rate for loan shall be adjusted timely and properly according to researches on economic and financial situation of Shijiazhuang City and the current development situation of privately-owned SMEs, so as to reduce financing cost for enterprises.

B) Further improve finance evaluation system. In economic indicators evaluation, financial sectors shall deter-mine indicators such as profit, deposit, etc. in line with real situations of privately-owned SMEs in Shijiazhuang, in order to avoid the impact on enter-prise development brought by unreasonable rules. Meanwhile, emerging industries and sunrise industries should be supported by loosening evaluation indicators. Preferential policies, flexible financing environment, as well as financing directions shall also be provided for pillar industries of local areas.

C) Further standardize financial business. Financial sectors should execute up-floating interest rate more regularly and formulate more detailed and rigid regulations. For example, standardizing intermediate businesses of banks that charges for loan consulting and financial advising shall be canceled; regulating the deposit-taking behavior of banks so as to prevent enterprises from being required by banks to deposit in huge sums of money. In the meantime, financial sectors are supposed to enhance working efficiency and service quality, take more measures in favor of enterprise development, and eliminate unfavorable services according to real situation. As for financing credit, the loan term can be extended appropriately according to risk level on the premise of ensuring capital safety.

D) Strengthen the consciousness of commercial banks about lending service for privately-owned SMEs. During the process of development, privately-owned SMEs find it difficult to meet the requirements of indicators in terms of scale, asset, financial regulation, enterprise credit, etc. They can be measured, however, in such aspects as credit standing of manager, risk level, business condition, repaying capability and development prospect. In the meantime, a credit rating system consistent with current situation of enterprise can be also set up in line with these factors to strengthen the consciousness of banks about lending service.

\subsubsection{Try new financing channels}

Aside from the above-mentioned macroscopic approach- es of alleviating financing difficulty, privately-owned SMEs can also add new financing means and channels on their own by breaking through existing patterns. Based on the economic features of Shijiazhuang City and research findings at home and abroad, the following financing channels are recommended for the sake of these enterprises:

\section{(1) Intangible assets pledge}

Financing difficulty is always a bottleneck restricting the development of privately-owned SMEs, even for innovative ones with independent intellectual property rights, who might be unable to convert scientific and technological achievements into products promptly due to capital shortage. Thus, it's hard for these enterprises to develop rapidly. Yet pledge loans in the form of intellectual property rights can serve as a new financing channel for this kind of enterprises.

Intangible assets guarantee is a challenge for enterprises if financial institutions intend to solve financing problems for privately-owned SMEs of scientific and technologic type in Shijiazhuang City. Thus it is necessary to change ways of guarantee. Experts of related fields can be gathered together to carry out studies on intellectual property loans and evaluate acquired intellectual property rights and patent rights with the help of law offices and evaluation agencies, so as to scheme out a complete loan business process, solving the fundamental problem of difficult evaluation and transference for highly qualified and reputable privately-owned SMEs of scientific and technologic type. However, financial institutions can narrow down the scope in the early stage of exploration. For example, they could try patent rights at first and then expand to other intellectual property rights with the gradually improved loan process. Banks should set up regulations for borrowers that funds can be only put in productions and operations to ease financial strain instead of investment and illegal business. Any enterprise would be disqualified from taking out loans upon discovery.

For scientific and technologic privately-owned SMEs with independent intellectual property rights, it is an effective way to solve the problem of capital shortage and reduce the influence of capital bottleneck in development by carrying out pledge loans in the form of intellectual property rights, which is to the benefit of the market transformation speed of intellectual property rights and the enhancement of core competitiveness of privatelyowned SMEs as well.

There are now quite many forms of newly-organized intangible assets that can be used as collateral for bank loans by privately-owned SMEs of scientific and technologic type with patent rights and copyrights.

(2) Establish mutual credit guarantee system of privately-owned SMEs by raising funds for mutual guarantee

It is generally acknowledged that the lack of collateral is one of the major problems of bank loans difficulty for privately-owned SMEs. Solving the problem of guarantee difficulty in enterprise loans has become an important 
requirement for enterprises to get bank credit. Privatelyowned SMEs are free to combine together and raise funds, which shall be deposited in banks as mutual guarantee funds. According to the amount of deposited funds, guaranteed enterprises with financing needs can be provided with loans of certain multiples.

\section{(3) Make private lending an effective way of financing for privately-owned SMEs}

With low credit level and insufficient assets for collateral, most privately-owned SMEs can hardly obtain guaranteed financing. Besides, bank loans cannot meet the demand of enterprises for funds timely due to complicated procedures and long time needed. Thus, private lending is supposed to become an effective way of financing for privately-owned SMEs under the circumstances. As a simple and flexible financing way with plentiful resources, private lending, to some extent, has alleviated the conflicted brought by insufficient bank credit funds in this ever-accelerated market economy. The government and local departments of Shijiazhuang City should encourage private lending to play a part in financing of privately-owned SMEs, attach importance to this effective financing way, bring it to the orbit of legal system, and improve the legal system constantly ${ }^{[4]}$.

No matter in what ways, however, it can never do without the joint effort of the government, banks and privately-owned SMEs in Shijiazhuang City. Long-term attention and support are still required for financing predicaments of enterprises.

\subsection{Promote the construction of public service platforms}

Firstly, service platforms of common technology. Scientific and technological resources, such as institutions of higher learning, institutes of science and technology, and enterprise technology center, should carry out researches on common key technologies so as to provide privatelyowned SMEs with support of core technologies. Scientific and technological talents shall also be encouraged to establish service platforms of common technology, offering services for privately-owned SMEs like product development, technological innovation, quality test and etc. Privately-owned SMEs should have access to public science and technology resources with low charges for technological detection and product identification. Secondly, service platforms of market expansion. Inter-active activities involving projects, technologies, demands and supplies, and marketing shall be organized regularly between large enterprises and privately-owned SMEs or between manufacturing enterprises and service enterprises, so as to provide them with convenience in cooperation of economic technologies, products and marketing. Support privately-owned SMEs to participate in all kinds of exhibitions and cooperative exchanges concerning large products and technologies at home and abroad. Thirdly, information service platforms. Administrative departments, judicial branches and utility service agencies of Shijiazhuang City are supposed to promote the construction of credit information sharing mechanism for private- ly-owned SMEs and provide relevant credit information inquiry service in accordance with laws. Support all kinds of information service agencies to innovate their service mode, and provide informatization service for privatelyowned SMEs including e-government affairs, ecommerce, online financing and marketing, so as to accelerate the close integration of innovative development and information construction of privately-owned SMEs.

\subsection{Vigorously implement talents project and improve the whole quality of enterprise person- nel}

Firstly, strengthen training for operators. Secondly, recruit talent from the whole society. Solve the brain drain problem of local regions by cross-regional introduction or direct recruitment of graduates in colleges. Thirdly, transform mechanisms and retain talents by giving out shares. Through accelerating the speed of operational mechanism transformation, implementing shareholding reform courageously, increasing the amount of technology stocks, and transferring part of stocks to excellent talents, enterprises can make them properly combine their own interests with enterprise interests. Fourthly, search for talents of inner-enterprise and make good use of them. Followup education should be given importance and all kinds of training and further education opportunities should be provide for talents in order to speed up the upgrading of knowledge for talents themselves ${ }^{[5]}$.

\section{Conclusions}

For those privately-owned SMEs who intend to achieve business goals, it is necessary to solve existing problems timely, seize opportunities and give full play to their strengths. Under the close guidance of the Scientific Outlook on Development, the government should increase the intensity of industrial structure adjustment, develop high and new technology industries vigorously, establish powerful service systems for privately-owned SMEs, and guide privately-owned SMEs to take the path of sustainable development

\section{References}

1. Lin Wenbin. A study on development strategies of SMEs of Shijiazhuang City in new economic situation[J]. China Business \& Trade, 2012, (29).

2. Jin Xingtong, Development strategies of privatelyowned SMEs[J]. Cooperative Economy \& Science, 2011, (8).

3. Liao Rongbi. On financing predicaments of SMEs and private financing reconstruction in post crisis era[J]. Commercial Times, 2010, (25).

4. Li Huajun. A study on small-business financing in China based on relationship lending [J]. Securities \& Futures of China, 2010, (5).

5. Wu Fenfa. A study on financing predicaments of SMEs and countermeasures[J]. Wealth Frontier, 2012, (10). 